\title{
A Sustainably Successful Entrepreneur with a Visionary Green-Minded Biotechnology: Shih Hao Tony Peng as a model
}

\author{
Chee Kong Yap
}

\author{
Department of Biology, Faculty of Science, Universiti Putra Malaysia, 43400 UPM, Serdang, Selangor Malaysia \\ *Corresponding author: yapckong@hotmail.com; yapchee@upm.edu.my
}

\begin{abstract}
This short communication paper describes Shih Hao Tony Peng (Tony) who is a sustainably successful entrepreneur with a visionary green-minded biotechnology in Asia. Mr. Tony possesses all the key traits of successful entrepreneurs especially key traits of a successful entrepreneur especially resilience capacity and future-oriented that make him a sustainably successful entrepreneur. This paperfeatures our honest appreciation on a sustainably successful person by taking Mr. Tony as a model, who has been fulfilling great advocated social responsibilities.
\end{abstract}

Keywords-Entrepreneur; Green biotechnology.

\section{WHO IS AN ENTREPRENEUR?}

An entrepreneur is defined as a person who sets up an enterprise or business, assuming and taking on financial risks in the investment by hoping of rewards and profit in the venture. However, only those with analytical mind and good managerial skills can foresee the future markets and is capable to maintain the organization in the long run (Khosla and Gupta, 2017; Duchek, 2018; Nuvolari et al., 2018). Therefore, untangling the traits of successful entrepreneurs is important to understanding, developing, and promoting these skills for the success of organizations (Khosla and Gupta, 2017). A lot of scientific literature especially based on Scopus database reporting the title on 'Entrepreneur' (Baumol, 2016; Przepiorka, 2016; Khosla and Gupta, 2017; Duchek, 2018; Nuvolari et al., 2018). This signifies the important roles played by entrepreneurs in the economy development of a nation. For example, Nuvolari et al. (2018)'s findings indicated the multidimensional nature of entrepreneurial success, comprising both a strictly economic and a "celebrity" dimension.

\section{MR. SHIH HAO TONY PENG AS A MODEL}

In this short communication article, allow me to introduce a sustainably successful entrepreneur with a visionary green-minded biotechnology in Asia. He is Mr.
Shih Hao Tony Peng (Tony) who is currently the Group Chairman and Chief Executive Officer (CEO) of All Cosmos Bio-Tech Holding Corporation (ACBT) (All Cosmos, 2019). He has performed well, and been able to manage, maintain and prosper his company growth over the past 20 years. His company will continue to prosper and sustainably successful in coming years. According to Brian Tracy, 'The true measure of the value of any business leader and manager is performance.'

According to Duchek (2018), to be sustainably successful, entrepreneur needs a resilience capacity. This empowers them to overwhelm desperate situations and even arise from failures sounder than before. Przepiorka (2016) showed that entrepreneurs were more futureoriented and professed their presence less fatalistically when compared those not interested in becoming entrepreneurs. I strongly believe that Mr. Tony possesses all the positive traits especially resilience capacity and future-oriented that make him a sustainably successful entrepreneur.

One of the ethical criteria in research is respect for persons. From my personal observation, Mr. Tony pays good respects for persons and knowledge. He is a learned and well educated person with good perceptions and new thoughts. He respects knowledge. He is an educated person because he listens to description of my academic life and he is also interested in my academic writing. His background in biotechnology renders him to understand relatively well about my ecotoxicological studies in Malaysia. He possesses a very good judgment based on the current plantation problems in Malaysia. He reasons analytically and critically on the problems faced by the planters and farmers in Malaysia. Besides the above characteristics, I do believe that his focus and discipline are making him a successful knowledgeable entrepreneur. A Sicilian proverb says 'You can tell an educated person by their talk and bells by their ringing.'

Mr. Tony's wisdom is unquestionable. He is a kind person with a heart to help more people. Besides 
respecting other people, he has helped numerous people in Malaysia. This is judged by his company' profile and successful stories (All Cosmos, 2019). I have over 20 years of experience of being a researcher specializing in monitoring and biomonitoring of heavy metal pollution in Malaysia (Yap, 2019). However, I am not sure if my scholarly outputs (193 papers indexed with an H-index 24 in Scopus as on April 25, 2019; Scopus author ID: 57007806600) will benefit our society if my publications just stay in the book shelf (as reading materials) without application of the knowledge in terms of acting as biotechnological tools for practical implementation. I am uncertain if an academician (like myself) can benefit the society with my accumulated knowledge.

Meanwhile, Mr. Tony has over 20 years of experience in the agricultural-based business in Malaysia, China, Indonesia, Vietnam and Philippines. He spent a lot of time on Research and Development (R and D) in agricultural biotechnology because of his passion in knowledge seeking. He is driven by a kind heart to help and to serve and to change and improve the livelihood of numerous people. He is on a mission for the betterment of society with an unshakable sense of purpose.

Mr. Tony has put his knowhow and expertise into practical application by introducing Effective Microorganisms (EM) in the fertilizers (with biodegradable biochemicals) to reduce Soil Pollution (SP) and to increase yields of crop production/plantations in Asia (All Cosmos, 2019). In particular, SP is one of my areas of study in which I have edited a book on SP (Yap, 2019). He has made a huge positive impact to Malaysian society by providing job opportunities and helping our local planters and farmers to catalyse their economic growth as well. Why I said 'he has made a huge positive impact' is because he is the mastermind or 'the DNA of a cell' where his company's commands derive from him. Only an organization with an educated and kind-hearted wise CEO is capable of making effective contribution to the society and serves the public community with passion and dignity. A Hebrew proverb says 'The greatest wisdom of all is kindness'.

Although he is a Taiwanese, his contribution to our Malaysian society is significant and cannot be ruled out easily. As an academician, I foresee more positive contribution to our society from his company since he is the CEO, as part of social responsibility. According to Khosla and Gupta (2017), the followings are the key traits of successful entrepreneurs, including 'comfort with uncertainty, laserlike focus and execution, flexibility in response to market needs, big picture perspective coupled with a detail orientation, and people management with the right balance of delegation'. I think Mr. Tony definitely fulfils all the above key traits as a sustainably successful entrepreneur. According to Winston Churchill, 'Responsibility is the price of greatness.' And I foreknow Mr Tony will be a great and more successful entrepreneur in future because he is going to make a positive difference in the lives of many and more people. This could be the reason why there is a positive relationship between the public interest and the advocated social responsibilities of successful entrepreneurs (Baumol, 2016).

\section{CONCLUDING REMARKS}

Finally, I hope this short communication article presenting my creditable views on passionate Mr. Tony will encourage the readers and promote human appreciation on the good, visionary and sustainably successful people.

\section{REFERENCES}

[1] All Cosmos. 2019.

http://cyrusitconsulting.com/allcosmos/ Searched on April 24, 2019.

[2] Baumol, W.J. 2016. On the Appropriate Social Responsibilities of successful Entrepreneurs. Business and Society 55(1):14-22.

[3] Duchek, S. 2018. Entrepreneurial resilience: a biographical analysis of successful entrepreneurs. International Entrepreneurship and Management 14(2):429-455.

[4] Khosla, A. and Gupta, P. 2017. Traits of successful entrepreneurs. Journal of Private Equity 20(3)12-15.

[5] Nuvolari, A., Toninelli, P.A., and Vasta, M. 2018. What makes a successful (and famous) entrepreneur? Historical evidence from Italy (XIX-XX centuries). Industrial and Corporate Change 27(1): 425-447.

[6] Przepiorka, A. 2016. What makes successful entrepreneurs different in temporal and goalcommitment dimensions? Time and Society 25(1):4060.

[7] Yap, C.K. 2019. Soil Pollution: Sources, Management Strategies and Health Effects. Editor. Nova Science Publishers, New York, USA. 